\title{
Systemic Light Chain Amyloidosis
}

\author{
Monique Minnema and Stefan Schönland
}

\subsection{Definition and Epidemiology}

Systemic light chain (AL) amyloidosis is a protein misfolding and deposition disorder with an incidence of 5-12 persons per million per year. Clonal plasma cells or rarely B cells produce immunoglobulin light chains with the potential to misfold. These light chains are deposited as extracellular amyloid fibrils in peripheral tissues and cause morbidity and mortality. Organs most frequently involved are the kidney, heart, liver, autonomic and peripheral nervous system, gastrointestinal tract, and soft tissue.

\subsection{Diagnosis}

AL amyloidosis should be suspected in any patient with a monoclonal gammopathy and a compatible clinical syndrome such as heart failure with a preserved ejection fraction, nephrotic

\footnotetext{
M. Minnema

Department of Hematology, UMC Utrecht Cancer Center, Utrecht, The Netherlands

S. Schönland $(\bowtie)$

Hematology, Oncology and Rheumatology, Medical Department V, University Hospital of Heidelberg, Heidelberg, Germany

e-mail: stefan.schoenland@med.uni-heidelberg.de
}

range proteinuria, unexplained weight loss, peripheral neuropathy, a bleeding diathesis, or carpal tunnel syndrome. Gammopathy work-up should include a serum-free light chain assay, immunofixation of serum and urine, bone marrow cytology, flow cytometry, histology and iFISH, and a full-body scan to exclude bone lesions due to symptomatic MM. AL amyloidosis is diagnosed by histopathology with Congo red staining and the typical apple-green birefringence under polarized light. Screening biopsies such as abdominal fat, rectum, salivary gland, or bone marrow as well as symptomatically involved organs can be utilized. The amyloid subtype has to be further confirmed by immunohistochemistry, immune electron microscopy, or laser microdissection and mass spectrometry.

\subsection{Classification}

AL amyloidosis can be classified by the origin of the underlying bone marrow disease: a clonal plasma cell or a lymphoid dyscrasia. Plasma cell dyscrasias can further be divided into monoclonal gammopathy, smoldering MM, and symptomatic MM. Finally, IgM-related AL amyloidosis is a specific entity with an underlying lymphocytic, lymphoplasmacytic, or a plasma cellular clone, commonly with cardiac and peripheral nervous system involvement. 


\subsection{Risk Factors and Prognostic Scores}

The underlying bone marrow disease as well as organ damage-related biomarkers can be utilized to stratify patients into risk groups. A bone marrow plasma cell infiltration above $10 \%$ (Hwa et al. 2016) and a high difference between involved and uninvolved serum-free light chain (dFLC) are negative prognostic factors (Kumar et al. 2012) for overall survival. Comparable to MM genetic aberrations can be detected on iFISH in plasma cell dyscrasias and be utilized to predict response to specific treatments (e.g., in patients with translocation $(11 ; 14) \mathrm{HDM} / \mathrm{HSCT}$ is more effective) (Bochtler et al. 2016).

The Mayo clinic first published a staging system utilizing NT-ProBNP and cardiac troponins (cTnI, cTnT) in 2004 which strongly predicted outcome. Median survival for patients in Stages I, II, and III were 26.4, 10.5., and 3.5 months (Dispenzieri et al. 2004a), and for the transplant group Stages I and II median were not reached, and Stage III median was 8.4 months (Dispenzieri et al. 2004b). This staging system was adapted in 2013 by a European cooperative approach and an ultra-high-risk patient group was identified with an NT-proBNP cut-off of $8500 \mathrm{ng} / \mathrm{L}$ (Stage IIIb) which must be considered transplant-ineligible (Wechalekar et al. 2013).

For patients with renal involvement, total proteinuria/24 $\mathrm{h}$ and estimated glomerular filtration rate (eGFR) can anticipate the risk for terminal renal failure (Palladini et al. 2014).

The depth of response is also a significant prognostic factor as patients achieving an amyloidosis VGPR (dFLC below $40 \mathrm{mg} / \mathrm{L}$ ) or CR after treatment have a significantly better outcome (Palladini et al. 2012).

\subsection{First-Line Treatment}

Risk-adapted treatment is preferred since most patients are fragile and do not tolerate standard used dosing regimens (see Table 81.1). Three categories are defined with low-risk patients,
Table 81.1 First-line treatment options according to risk status

\begin{tabular}{|c|c|}
\hline Risk status & Treatment \\
\hline $\begin{array}{l}\text { Low-risk } \\
\text { Stage I }\end{array}$ & $\begin{array}{l}\text { - }( \pm \text { induction treatment }) \text { MEL } \\
\left(200 \mathrm{mg} / \mathrm{m}^{2}\right)+\text { auto-HSCT } \\
\text { - CYBorD }\end{array}$ \\
\hline $\begin{array}{l}\text { Intermediate-risk } \\
\text { Stages II-IIIa }\end{array}$ & $\begin{array}{l}- \text { MEL-DEX } \\
\text { - CYBorD } \\
\cdot \text { Bortezomib-MEL-DEX or } \\
\text { LENA-MEL-DEX }\end{array}$ \\
\hline $\begin{array}{l}\text { High-risk } \\
\text { Stage IIIb }\end{array}$ & $\begin{array}{l}\text { - Low-dose therapies } \\
\text { - Bortezomib weekly monotherapy }\end{array}$ \\
\hline CYBorD & lophosphamide, $\quad$ bortezomib \\
\hline
\end{tabular}
dexamathasoone

transplant eligible, being a minority $(\leq 20 \%)$. High-risk patients are defined by Stage IIIb and/ or having NYHA class III or IV heart disease. Other factors to consider are age, performance status, eGFR, and systolic blood pressure (Palladini and Merlini 2016). Frequent assessments of hematological response during treatment are needed, and the goal is to achieve a CR or VGPR as a deep hematologic response is closely related to survival. Patients having a hematologic response may gradually achieve an organ response.

\subsection{Second-Line Treatment}

There is no randomized trial data to guide treatment at relapse. Patients with a good duration of response who tolerate initial treatment well may be retreated with the same initial regimen. Patients with a poor response are best treated with an alternative agent combination using agents to which the patient has not been exposed, palliation or in a clinical trial tailored to the individual patient in terms of their age, comorbidities, extent of organ involvement, and the patient's wishes. Lenalidomide and pomalidomide can be considered in relapsed disease although data on durability of response are limited (Dispenzieri et al. 2007; Palladini et al. 2017). Toxicity with lenalidomide is a significant issue, and it is recommended to start at a dose of $15 \mathrm{mg}$ daily, with further dose reduction based on glomerular filtration rate (GFR) (Dispenzieri et al. 2007). 


\subsection{Autologous HSCT}

\subsubsection{Indication}

Eligibility criteria for autologous HSCT are variable depending on the transplanting center. However, the usual eligibility criteria include age $\leq 70$ years, performance status $0-2$, NYHA class I or II, absence of significant clinical cardiac involvement (NT pro BNP $<5000 \mathrm{ng} / \mathrm{L}$. left ejection fraction $\geq 45$ to $50 \%$ ), absence of severe orthostatic hypotension (i.e., systolic blood pressure $\geq 90 \mathrm{~mm} \mathrm{Hg}$ ), and eGFR $>40 \mathrm{~mL} / \mathrm{min}$. Induction therapy before stem cell mobilization can be given, especially in patients who fulfill (smoldering) myeloma definition criteria, i.e., $\geq 10 \%$ bone marrow plasma cell infiltration.

The correct selection of patients is extremely important since the mortality associated with autologous HCT in AL amyloidosis can be unacceptable high if not done properly. Since the selection criteria also include the cardiac biomarkers, treatment-related mortality has dropped from around $20 \%$ to $5 \%$; also see Table 81.2 (Gertz et al. 2013).

\subsubsection{Recommended}

Stem cell mobilization and leucapheresis can be associated with unusual morbidity, and a syndrome of hypoxia and hypotension has been described both during mobilization with G-CSF and during the leucapheresis procedure itself, probably as a result of a capillary leak syndrome triggered by G-CSF. Therefore, use of reduced doses of G-CSF (such as $10 \mu \mathrm{g} / \mathrm{kg}$ per day for 4-5 days) is recommended. In low-burden disease (i.e., plasma cells $<10 \%$ ), the use of CY mobilization chemotherapy does not seem to be necessary.
Conditioning regimens are based on highdose MEL. The usual MEL dose is $200 \mathrm{mg} / \mathrm{m}^{2}$, since lower-dose melphalan is associated with decreased hematological response and PFS and therefore other treatment non-transplant options may be more suitable (Cibeira et al. 2011).

\subsubsection{Results}

Figure 81.1 shows OS of auto-HSCT until 2010. In Table 81.2 the more recent publications of the last 10 years have been summarized. The use of induction therapy before HSCT has been more frequently applied and seems to demonstrate better hematologic responses than HSCT alone.

\subsection{Allogeneic HCT}

The largest retrospective analysis on allo-HCT for AL amyloidosis was performed by the EBMT in 2006 (Schönland et al. 2006). Nineteen patients were analyzed. Seven patients received MAC, and eight RIC. $40 \%$ of patients died of TRM. Longterm survival and sustained CR were achieved in seven patients and were associated with chronic GVHD in the majority of them. DLI has been successfully performed in a few patients with AL amyloidosis, thereby demonstrating a potent "graft-versus-plasma cell-dyscrasia" effect.

The EBMT initiated a noninterventional prospective study (NIS) for patients with AL amyloidosis undergoing allo-HSCT. Preliminary results have been presented in 2016 with improved overall survival (see Fig. 81.2). Allo-HSCT after RIC can be discussed as a treatment option for relapse after auto-HCT in patients $<60$ years with preserved organ functions and a HLA-identical donor. It might be a curative treatment for highly selected patients. 
Table 81.2 Summary of the outcome of patients with systemic AL amyloidosis undergoing autologous stem cell transplantation, according to the more recent publications

\begin{tabular}{|c|c|c|c|c|c|}
\hline Source & Type & $\begin{array}{l}\text { No. of } \\
\text { patients }\end{array}$ & $\begin{array}{l}\text { Overall response } \\
\text { rate }(\mathrm{CR}) \%\end{array}$ & TRM (\%) & $\begin{array}{l}\text { Overall survival } \\
(\%)\end{array}$ \\
\hline $\begin{array}{l}\text { Landau et al. } \\
\text { (2017) }\end{array}$ & Retrospective & 143 & $\begin{array}{l}\text { CR } 43 \% \text { at } \\
12 \text { months ( } 83 \text { pts } \\
\text { only) }\end{array}$ & $5 \%$ & Median 10.4 years \\
\hline $\begin{array}{l}\text { Sanchorawala } \\
\text { et al. (2015) }\end{array}$ & $\begin{array}{l}\text { Prospective bortezomib- } \\
\text { DEX induction }\end{array}$ & 35 & $\begin{array}{l}\text { ORR } 100 \% \\
\text { CR } 63 \%\end{array}$ & $8.5 \%$ & 5 years; $83 \%$ \\
\hline $\begin{array}{l}\text { Hazenberg et al. } \\
(2015)\end{array}$ & $\begin{array}{l}\text { Prospective VCR-adriam- } \\
\text { DEX induction }\end{array}$ & 69 & $\begin{array}{l}\text { ORR } 46 \% \\
\text { CR } 13 \%\end{array}$ & $4 \%$ & Median 10 years \\
\hline $\begin{array}{l}\text { Parmar et al. } \\
\text { (2014) }\end{array}$ & Retrospective & 80 & $\begin{array}{l}\text { ORR } 75 \% \\
\text { CR } 18.6 \%\end{array}$ & $7.5 \%$ & 10 years, $56 \%$ \\
\hline $\begin{array}{l}\text { Huang et al. } \\
\text { (2014) }\end{array}$ & $\begin{array}{l}\text { Prospective bortezomib- } \\
\text { DEX induction in } 28 \mathrm{pts}\end{array}$ & 56 & $\begin{array}{l}\text { ORR } 85.7 \% \text { and } \\
53.5 \% \\
\text { CR } 67.9 \% \text { and } \\
35.7 \% \\
\text { Both at } 12 \text { months }\end{array}$ & $3.6 \%$ & $\begin{array}{l}2 \text { years } \\
95 \% \text { and } 69.4 \%\end{array}$ \\
\hline $\begin{array}{l}\text { D'Souza et al. } \\
(2015)\end{array}$ & Retrospective & 1536 & $\begin{array}{l}\text { ORR } 71 \% \\
\text { CR } 37 \% \text { (2007- } \\
2012 \text { cohort) }\end{array}$ & $\begin{array}{l}5 \%(2007- \\
2012 \text { cohort })\end{array}$ & $\begin{array}{l}5 \text { years } 77 \% \\
(2007-2012 \\
\text { cohort) }\end{array}$ \\
\hline $\begin{array}{l}\text { Cibeira et al. } \\
(2011)\end{array}$ & Retrospective & 421 & CR $34 \%$ & $\begin{array}{l}5.6 \% \\
\text { (2004-2008 } \\
\text { cohort) }\end{array}$ & Median 6.3 years \\
\hline
\end{tabular}

Fig. 81.1 Autologous EBMT data (patients treated until 2010)

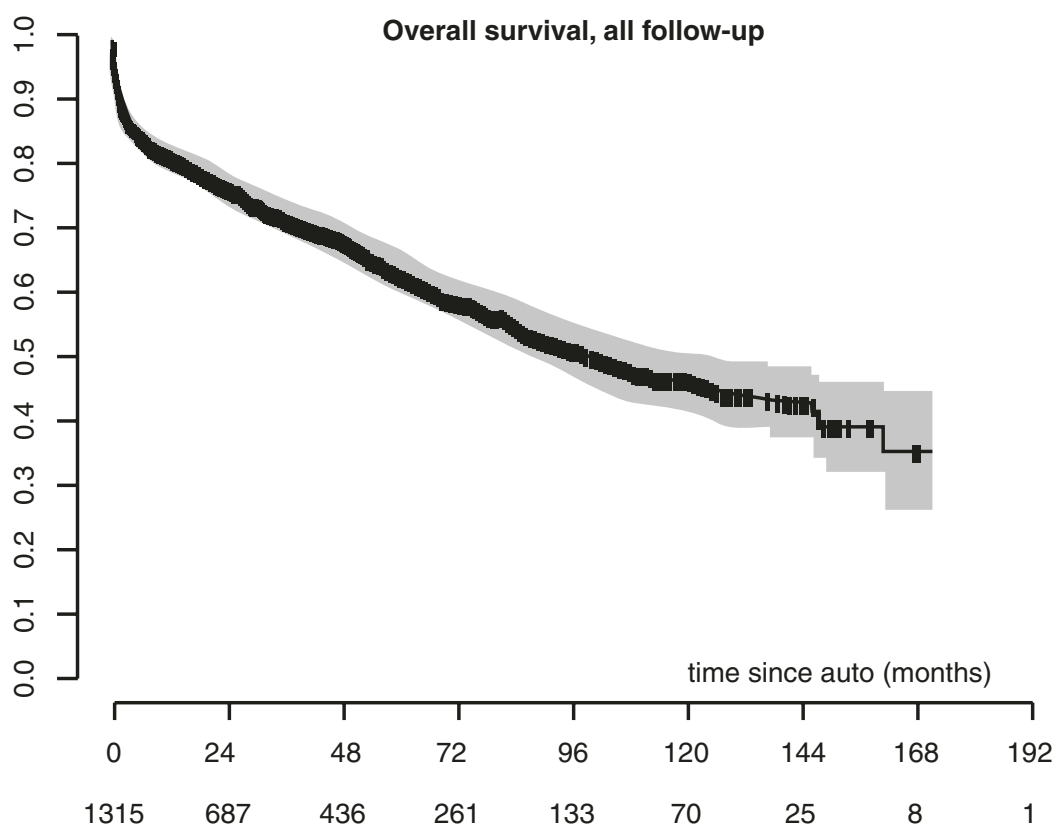


Fig. 81.2 Long-term overall survival after allo-HSCT, an EBMT analysis of patients with AL amyloidosis

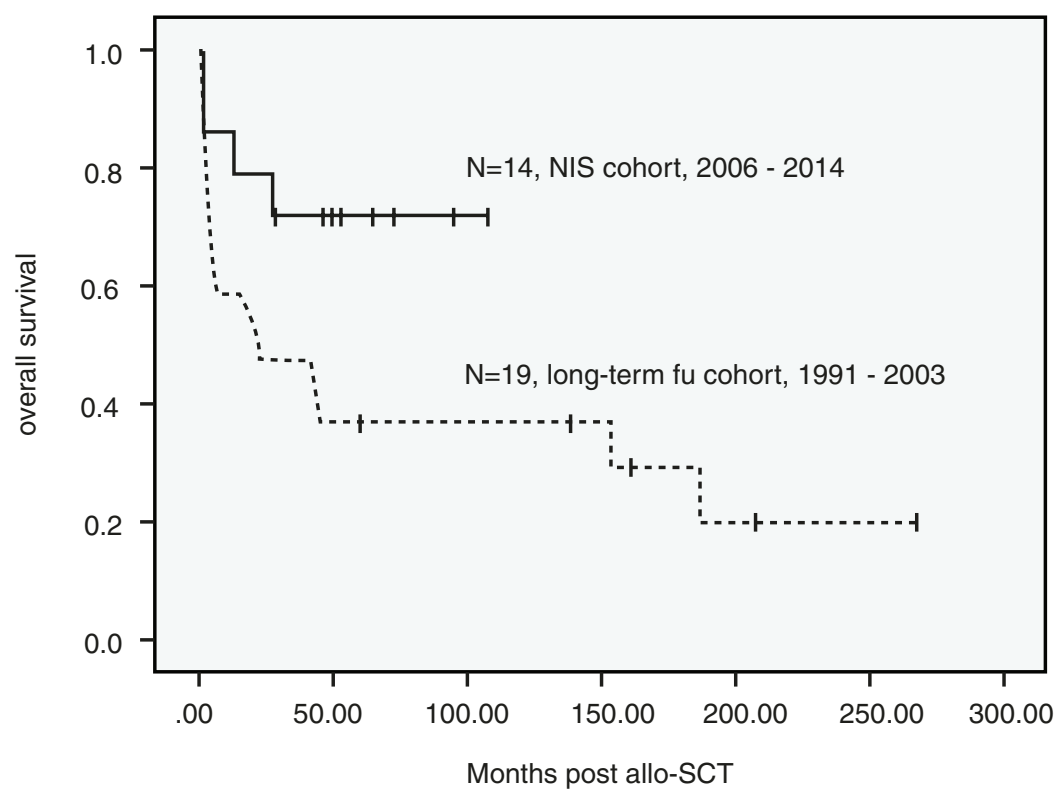

\section{Key Points}

- AL amyloid therapy is directed against the underlying B cell clone

- Hematological response is the goal of therapy and improves survival

- Intensity of chemotherapy has to be risk adapted

- High-dose chemotherapy with autoHSCT is the therapy of choice for lowrisk patients

- Allo-HSCT might be a curative treatment option for relapse after auto-HCT in younger patients with preserved organ functions and a HLA-identical donor

\section{References}

Bochtler T, Hegenbart U, Kunz C, et al. Prognostic impact of cytogenetic aberrations in AL amyloidosis patients after high-dose melphalan: a long-term follow-up study. Blood. 2016;128:594-602.

Cibeira MT, Sanchorawala V, Seldin DC, et al. Outcome of AL amyloidosis after high-dose melphalan and autologous stem cell transplantation: long-term results in a series of 421 patients. Blood. 2011;118:4346-52.

D'Souza A, Dispenzieri A, Wirk B, et al. Improved outcomes after autologous hematopoietic cell trans- plantation for light chain amyloidosis: a Center for International Blood and Marrow Transplant Research Study. J Clin Oncol. 2015;33:3741-9.

Dispenzieri A, Gertz MA, Kyle RA, et al. Serum cardiac troponins and N-terminal pro-brain natriuretic peptide: a staging system for primary systemic amyloidosis. J Clin Oncol. 2004a;22:3751-7.

Dispenzieri A, Gertz MA, Kyle RA, et al. Prognostication of survival using cardiac troponins and N-terminal pro-brain natriuretic peptide in patients with primary systemic amyloidosis undergoing peripheral blood stem cell transplantation. Blood. 2004b;104:1881-7.

Dispenzieri A, Lacy MQ, Zeldenrust SR, et al. The activity of lenalidomide with or without dexamethasone in patients with primary systemic amyloidosis. Blood. 2007;109:465-70.

Gertz MA, Lacy MQ, Dispenzieri A, et al. Refinement in patient selection to reduce treatment-related mortality from autologous stem cell transplantation in amyloidosis. Bone Marrow Transplant. 2013;48:557-61.

Hazenberg BP, Croockewit A, van der Holt B, DutchBelgian Cooperative Trial Group for Hematology Oncology, et al. Extended follow up of high-dose melphalan and autologous stem cell transplantation after vincristine, doxorubicin, dexamethasone induction in amyloid light chain amyloidosis of the prospective phase II HOVON-41 study by the Dutch-Belgian Co-operative Trial Group for Hematology Oncology. Haematologica. 2015;100:677-82.

Huang X, Wang Q, Chen W, et al. Induction therapy with bortezomib and dexamethasone followed by autologous stem cell transplantation versus autologous stem cell transplantation alone in the treatment of renal AL amyloidosis: a randomized controlled trial. BMC Med. 2014;12:2. 
Hwa YL, Kumar SK, Gertz MA, et al. Induction therapy pre-autologous stem cell transplantation in immunoglobulin light chain amyloidosis: a retrospective evaluation. Am J Hematol. 2016;91:984-8.

Kumar S, Dispenzieri A, Lacy MQ, et al. Revised prognostic staging system for light chain amyloidosis incorporating cardiac biomarkers and serum free light chain measurements. J Clin Oncol. 2012;30:989-95.

Landau H, Smith M, Landry C, et al. Long-term event-free and overall survival after risk-adapted melphalan and SCT for systemic light chain amyloidosis. Leukemia. 2017;31:136-42.

Palladini G, Dispenzieri A, Gertz MA, et al. New criteria for response to treatment in immunoglobulin light chain amyloidosis based on free light chain measurement and cardiac biomarkers: impact on survival outcomes. J Clin Oncol. 2012;30:4541-9.

Palladini G, Hegenbart U, Milani P, et al. A staging system for renal outcome and early markers of renal response to chemotherapy in AL amyloidosis. Blood. 2014; 124:2325-32.

Palladini G, Merlini G. What is new in diagnosis and management of light chain amyloidosis? Blood. 2016;128:159-68.

Palladini G, Milani P, Foli A, et al. A phase 2 trial of pomalidomide and dexamethasone rescue treat- ment in patients with AL amyloidosis. Blood. 2017;129:2120-3.

Parmar S, Kongtim P, Champlin R, et al. Auto-SCT improves survival in systemic light chain amyloidosis: a retrospective analysis with 14-year follow-up. Bone Marrow Transplant. 2014;49:1036-41.

Sanchorawala V, Brauneis D, Shelton AC, et al. Induction therapy with bortezomib followed by bortezomibhigh dose melphalan and stem cell transplantation for light chain amyloidosis: results of a prospective clinical trial. Biol Blood Marrow Transplant. 2015;21:1445-51.

Schönland SO, Lokhorst H, Buzyn A, Chronic Leukemia Working Party, Myeloma Subcommittee of the European Cooperative Group for Blood and Marrow Transplantation, et al. Allogeneic and syngeneic hematopoietic cell transplantation in patients with amyloid light-chain amyloidosis: a report from the European Group for Blood and Marrow Transplantation. Blood. 2006;107:2578-84.

Wechalekar AD, Schonland SO, Kastritis E, et al. A European collaborative study of treatment outcomes in 346 patients with cardiac stage III AL amyloidosis. Blood. 2013;121:3420-7.

Open Access This chapter is licensed under the terms of the Creative Commons Attribution 4.0 International License (http://creativecommons.org/licenses/by/4.0/), which permits use, sharing, adaptation, distribution and reproduction in any medium or format, as long as you give appropriate credit to the original author(s) and the source, provide a link to the Creative Commons license and indicate if changes were made.

The images or other third party material in this chapter are included in the chapter's Creative Commons license, unless indicated otherwise in a credit line to the material. If material is not included in the chapter's Creative Commons license and your intended use is not permitted by statutory regulation or exceeds the permitted use, you will need to obtain permission directly from the copyright holder.

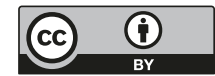

